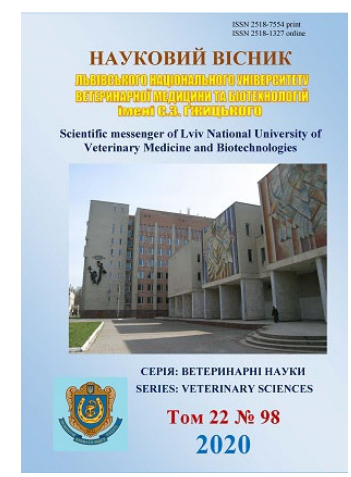

\author{
Науковий вісник Дьвівського національного університету \\ ветеринарної медицини та біотехнологій імені С.3. Гжицького. \\ Серія: Ветеринарні науки \\ Scientific Messenger of Lviv National University \\ of Veterinary Medicine and Biotechnologies. \\ Series: Veterinary sciences
}

UDC 636.22/28:612.

\title{
Age dynamics of hematological indices in dry cows
}

\author{
L. V. Koreyba, Y. V. Duda \\ Dniprovsky State Agro-Economical University, Dnipro, Ukraine
}

Article info

Received 16.03.2020 Received in revised form 16.04.2020 Accepted 17.04.2020

Dnipro State Agrarian and Economic University, Serhiya Yefremova Str., 25, Dnipro, 49000, Ukraine.

Tel.: +38-056-68-33-77 E-mail:lyudkorflk@gmail.com
Koreyba, L. V., \& Duda, Y. V. (2020). Age dynamics of hematological indices in dry cows. Scientific Messenger of Lviv National University of Veterinary Medicine and Biotechnologies. Series: Veterinary sciences, 22(98), 42-45. doi: 10.32718/nvlvet9807

The requirement for the study of blood parameters is determined by its physiological significance and changes that occur in different physiological and pathological conditions. The hematological profile is an important criterion that shows the physiological condition of animals. The physiological changes of blood in cows have been established concerning the conditions of keeping and feeding, hygienic parameters, in the dynamics of the dry season, in different seasons of the year, etcetera. We have not found any information on studies of the dynamics of blood parameters in pregnant animals, depending on their age, in the study of literary sources in recent years. The purpose of our work was to study the age-related dynamics of hematological blood parameters in cows during the dry period. Our studies aimed to determine the hematological indices of Holstein breed cows in the physiological course of the prenatal period during the dry period, depending on the number of deep calving. Control and experimental groups were formed on the principle of group-analogues (by breed, age, sex, physiological state, weight, milk productivity). Animals kept in typical rooms with satisfactory microclimate parameters (in winter) and at camps (in summer). Laboratory studies were carried out in the laboratory of the Dnipro State Agrarian and Economic University. Hematologic studies were performed according to the following indicators: erythrocytes, hemoglobin, color index, erythrocyte sedimentation rate, leukocytes, monocytes, lymphocytes, neutrophils with rod-like shape and segmented nucleus, basophils and eosinophils according to conventional methods. The results of our studies indicate that the lowest number of erythrocytes was detected in the cows of the sixth calving and the highest hemoglobin content, which led to the rise of the color index - in cows of the fifth pregnancy present the reverse tendency; increase to the maximum values of the number of leukocytes in cows of the third body (1.32 times), which is a reflection of the greater reactivity of the body of cows of this age group; a probable decrease (by $10.59 \%, P<0.05$ ) of lymphocyte counts was found in sixth-calf cows, indicating a weakened immune response; also increased eosinophils almost 1.75 times $(P<0.05)$ compared to fifth pregnancy; the trend of a gradual decrease in the number of segmented neutrophils in calving cows is followed by a second to fifth pregnancy and a significant reduction in the number of stab neutrophils in cows of the fifth pregnancy of up to $1.33 \%$.

Key words: cows. dry period, morphological indices, haematological research.

\section{Вікова динаміка гематологічних показників у сухостійних корів}

\author{
Л. В. Корейба, Ю. В. Дуда
}

Дніпровський державний аграрно-економічний університет, м. Дніпро, Україна

\footnotetext{
Потреба у дослідженні показників крові визначається їі фізіологічним значенням $і$ змінами, які настають за різних фізіологічних та патологічних станів. Гематологічний профіль є важливим критерієм, який показує фізіологічний стан тварин. Фізіологічні зміни крові у корів встановлено стосовно умов утримання та годівлі, зоогігієнічних параметрів, в динаміці сухостійного періоду, за різних сезонів року тощо. При опраџюванні літературних джерел останніх років нами не знайдено інформації щзодо досліджень динаміки показників крові у вагітних тварин залежно від їхнього віку. Мета нашої роботи полягала у вивченні вікової динаміки гематологічних показників крові у корів в період сухостою. Намі дослідження були спрямованими на визначення гематологічних
} 
показників тільних корів голштинської породи за фізіологічного перебігу дородового періоду в період сухостійного періоду залежно від кількості тільностей. Контрольні та дослідні групи формувались за принципом груп-аналогів (за породою, віком, статтю, фізіологічним станом, масою, молочною продуктивністю). Утримання тварин взимку - стійлове в типових приміщеннях із задовільними параметрами мікроклімату, а літом - в таборах. Лабораторні дослідження проводили в лабораторії Дніпровського державного аграрно-економічного університету. Гематологічні дослідження проводили за такими показниками: еритрочити, гемоглобін, кольоровий показник, ШОЕ, лейкоцити, моноцити, лімфоцити, паличко- та сегментоядерні нейтрофіли, базофіли і еозинофіли, керуючись загальноприйнятими методиками. Результати отриманих нами досліджень свідчать про те, щзо у корів шостої тільності виявлена найнижча кількість еритроцитів на фоні найвищого вмісту гемоглобіну, які призвели до зростання кольорового показника; у корів n'ятої вагітності - зворотна тенденція; збільшення до максимальних значень кількості лейкоиитів у корів третьої тільності (в 1,32 разу порівняно з попередньою), щчо є відображенням більшої реактивності організму корів даної вікової групи; вірогідне зниження (на 10,59\%, Р < 0,05) кількості лімфоцитів встановлено у корів шостої тільності, шчо вказує на послаблення імунної відповіді; також спостерігається збільшення кількості еозинофілів майже в 1,75 разу (P < 0,05$)$ порівняно $з$ n'ятою вагітністю; тенденція поступового зниження кількості сегментоядерних нейтрофілів у глибокотільних корів прослідковується з другої по п'яту вагітність та суттєве зниження кількості паличкоядерних нейтрофілів у корів п'ятої тільності до $1,33 \%$.

Ключові слова: корови, сухостійний період, морфологічні показники, гематологічне дослідження.

\section{Вступ}

Потреба у дослідженні показників крові визначається ії фізіологічним значенням і змінами, які настають за різних фізіологічних та патологічних станів (Kudrjavcev \& Kudrjavceva, 1984; Simonjan \& Hisamutdinov, 1995; Zamazii et al., 2015; Kulyaba et al., 2019; Grymak et al., 2020). Гематологічний профіль є важливим критерієм, який відображає фізіологічний стан тварин. Фізіологічні зміни крові у корів встановлено стосовно умов утримання та годівлі, зоогігієнічних параметрів, в динаміці сухостійного періоду, за різних сезонів року тощо (Rihter et al., 1982; Kondrahin et al., 1985; Petrovskij, 1995; Levchenko et al., 2002; Duda, 2005; Vlizlo et al., 2012).

Фактори природної резистентності організму корів різних порід і віку в процесі вагітності вивчали багато авторів. Виявлена певна їх залежність від періоду тільності та сезону року (Rihter et al., 1982; Kondrahin et al., 1985; Levchenko et al., 2002; Koreiba, 2019; Koreiba \& Duda, 2019). Але при опрацюванні літературних джерел останніх років нами не знайдено інформації щодо досліджень динаміки показників крові у вагітних тварин залежно від їхнього віку.

Тому мета нашої роботи полягала у вивченні вікової динаміки гематологічних показників крові у корів в період сухостою.

\section{Матеріал і методи досліджень}

У дослідженнях використано понад 130 корів голштинської чорно-рябої породи з молочною продуктивністю 5-6 тис. кг за лактацію.

Утримання тварин взимку - стійлове в типових приміщеннях із задовільними параметрами мікроклімату, а літом - в таборах.

Вагітні тварини були під постійним ветеринарним контролем, роди відбувались в спеціально обладнаному родильному приміщенні.

Контрольні та дослідні групи формувались за принципом груп-аналогів (за породою, віком, статтю, фізіологічним станом, масою, молочною продуктивністю).
Лабораторні дослідження проводили в лабораторії Дніпровського державного аграрно-економічного університету.

Наші дослідження були спрямованими на визначення гематологічних показників тільних корів голштинської породи за фізіологічного перебігу дородового періоду в період сухостійного періоду залежно від кількості тільностей.

Гематологічні дослідження проводили за такими показниками: еритроцити, гемоглобін, кольоровий показник, ШОЕ, лейкоцити, моноцити, лімфоцити, паличко- та сегментоядерні нейтрофіли, базофіли i еозинофіли, керуючись загальноприйнятими методиками (Kondrahin et al., 1985; Levchenko et al., 2002; Vlizlo et al., 2012).

Різницю між двома величинами вважали вірогідною за $* \mathrm{P}<0,05$ та $* * \mathrm{P}<0,01$.

\section{Результати та їх обговорення}

Виходячи з отриманих нами даних гематологічних досліджень (табл. 1), бачимо, що кількість еритроцитів і вміст гемоглобіну були на верхній межі норми (Kudrjavcev \& Kudrjavceva, 1984; Kondrahin et al., 1985; Levchenko et al., 2002; Vlizlo et al., 2012). Але, зважаючи на те, що голштинська порода $\epsilon$ високопродуктивною, норми показників гемопоезу в них дещо вищі, ніж у менш продуктивних порід.

При цьому виявлена і вікова мінливість цих показників. Найнижча кількість еритроцитів спостерігалась у корів шостої тільності, але на фоні найвищого вмісту гемоглобіну у цієї вікової групи кольоровий показник був вірогідно найвищим. У корів п'ятої вагітності виявлена зворотна тенденція - найвищий вміст еритроцитів на фоні найнижчого вмісту гемоглобіну та, внаслідок цього, найнижчий кольоровий показник.

Зміни ШОЕ були не вірогідними - $з$ максимумом за третьої тільності та мінімумом за п'ятої. Виявлено також збільшення до максимальних значень кількості лейкоцитів у корів третьої тільності (в 1,32 разу порівняно з попередньою), що, на нашу думку, є відображенням більшої реактивності організму корів цієї вікової групи. 
Таблиця 1

Гематологічні показники у сухостійних корів залежно від кількості тільностей $(\mathrm{M} \pm \mathrm{m})$

\begin{tabular}{lrrrrr}
\hline \multirow{2}{*}{\multicolumn{1}{c}{ Показники }} & \multicolumn{5}{c}{ Тільність } \\
\cline { 2 - 6 } & \multicolumn{1}{c}{ Друга } \\
& \multicolumn{1}{c}{ Третя 19$)$} & $\begin{array}{c}\text { Четверта } \\
(\mathrm{n}=11)\end{array}$ & $\begin{array}{c}\text { П'ята } \\
(\mathrm{n}=5)\end{array}$ & $\begin{array}{c}\text { Шоста } \\
(\mathrm{n}=6)\end{array}$ \\
\hline Еритроцити, Т/л & $7,34 \pm 0,18$ & $7,69 \pm 0,26$ & $6,45 \pm 0,53$ & $7,14 \pm 0,25$ & $6,18 \pm 0,3222,33,5$ \\
Гемоглобін, Г/л & $117,39 \pm 4,68$ & $117,99 \pm 6,02$ & $117,19 \pm 6,44$ & $100,77 \pm 3,46^{22,3,4}$ & $133,44 \pm 6,077^{2,55}$ \\
Кольоровий показник & $0,80 \pm 0,03$ & $0,78 \pm 0,06$ & $0,92 \pm 0,09$ & $0,71 \pm 0,04^{4}$ & $1,09 \pm 0,14^{2,5}$ \\
ШОЕ, мм/год & $1,18 \pm 0,07$ & $1,31 \pm 0,11$ & $1,15 \pm 0,05$ & $1,00 \pm 0,06^{2,3}$ & $1,20 \pm 0,15$ \\
Лейкоцити, Г/л & $7,93 \pm 0,60$ & $10,50 \pm 1,44$ & $8,62 \pm 1,33$ & $8,85 \pm 0,66$ & $6,85 \pm 0,68^{3}$ \\
\hline
\end{tabular}

Примітка: ${ }^{2} \mathrm{P}<0,05,{ }^{22} \mathrm{P}<0,01$ стосовно до другої тільності; ${ }^{3} \mathrm{P}<0,05,{ }^{33} \mathrm{P}<0,01$ стосовно до третьої тільності;

${ }^{4} \mathrm{P}<0,05,{ }^{44} \mathrm{P}<0,01$ стосовно до четвертої тільності; ${ }^{5} \mathrm{P}<0,05,{ }^{55} \mathrm{P}<0,01$ стосовно до п'ятої тільності

Зі зміною загальної кількості лейкоцитів одночасно відбулися певні зміни у вмісті окремих форм цих клітин (рис. 1).

Крім нейтрофілів, важлива роль у процесах захисту організму належить лімфоцитам, які беруть участь у всіх імунологічних реакціях і $є$ головними ефекторами в імунній відповіді.

У корів 3 другої по п'яту вагітності лімфоцити не мали вірогідних коливань, але 3 шостої тільності нами встановлене вірогідне зниження кількості цих клітин на $10,59 \%(\mathrm{P}<0,05)$ порівняно 3 попереднім періо- дом. Лімфоцитопенія вказує на послаблення імунної відповіді у тварин.

Як відомо, еозинофіли, як і нейтрофільні гранулоцити, є фагоцитами й цитотоксичними клітинами. В наших дослідах у корів шостої тільності кількість еозинофілів була вища майже в 1,75 разу $(\mathrm{P}<0,05)$ порівняно $з$ п'ятою.

3 другої по п'яту тільності прослідковується тенденція поступового зниження кількості сегментоядерних нейтрофілів, разом 3 тим паличкоядерні суттєво не змінювались, окрім корів п'ятої тільності, у яких виявлено різке зниження цього показника до 1,33%.

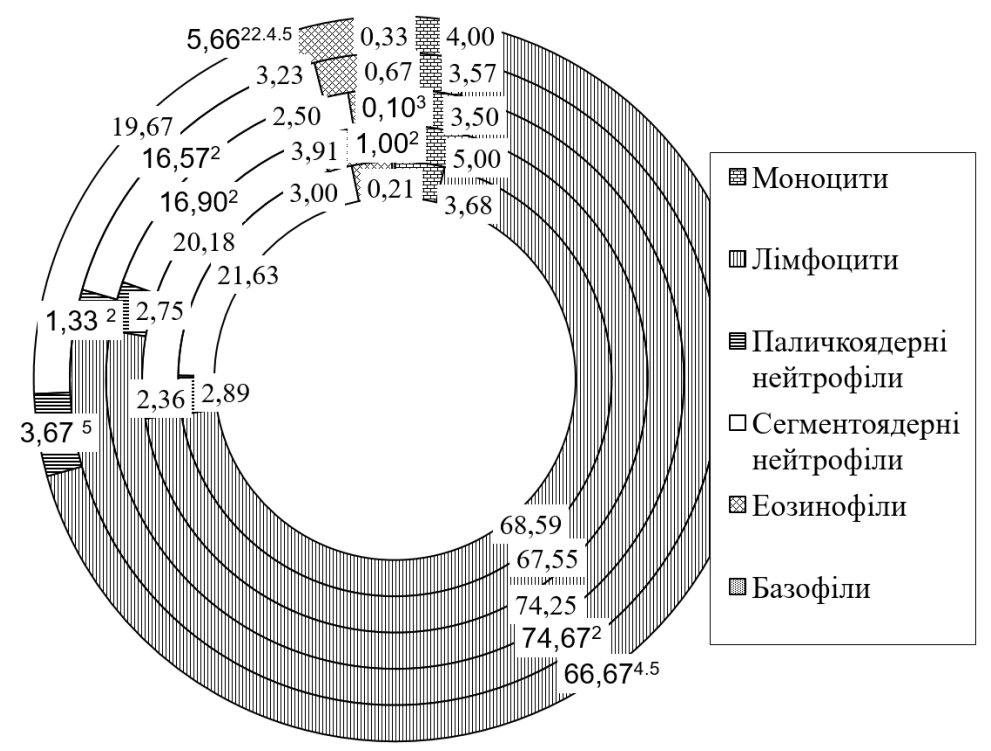

Рис. 1. Лейкоформула крові у сухостійних корів залежно від кількості тільностей, \% Примітка: ${ }^{2} \mathrm{P}<0,05 ;{ }^{22} \mathrm{P}<0,01$ стосовно до другої тільності; ${ }^{3} \mathrm{P}<0,05 ;{ }^{33} \mathrm{P}<0,01$ стосовно до третьої тільності; ${ }^{4} \mathrm{P}<0,05 ;{ }^{44} \mathrm{P}<0,01$ стосовно до четвертої тільності; ${ }^{5} \mathrm{P}<0,05 ;{ }^{55} \mathrm{P}<0,01$ стосовно до п'ятої тільності

\section{Висновки}

Виявлені коливання показників гематологічного статусу глибокотільних корів чорно-рябої голштинської породи залежності від їхнього віку та кількості отелень:

- у корів шостої тільності виявлена найнижча кількість еритроцитів на фоні найвищого вмісту гемоглобіну, які призвели до зростання кольорового показника; у корів п'ятої вагітності - зворотна тенденція;

- з'ясовано збільшення до максимальних значень кількості лейкоцитів у корів третьої тільності (в 1,32 разу порівняно з попередньою), що є відображенням більшої реактивності організму корів даної вікової групи;

- вірогідне зниження (на 10,59 \%, Р < 0,05) кількості лімфоцитів встановлено у корів шостої тільності, що вказує на послаблення імунної відповіді на фоні збільшення кількості еозинофілів майже в 1,75 разу $(\mathrm{P}<0,05)$ порівняно 3 п’ятою вагітністю;

- прослідковується тенденція поступового зниження кількості сегментоядерних нейтрофілів у глибокотільних корів 3 другої по п’яту вагітність та суттєве зниження кількості паличкоядерних нейтрофілів у 
корів п’ятої тільності до 1,33%.

Перспективи подальших досліджень полягають у вивченні показників клітинного і гуморального імунітету та неспецифічної реактивності організму глибокотільних корів.

\section{References}

Duda, Yu. V. (2005). Osoblyvosti pryrodnoi rezystentnosti koriv holshtynskoi porody riznoho fiziolohichnoho stanu za vplyvu biolohichno aktyvnykh rechovyn (propolisu ta hidrohumatu): avtoref. dys... kand. vet. nauk.: 03.00.13. K. (in Ukrainian).

Grymak, Y., Skoromna, O., Stadnytska, O., Sobolev, O., Gutyj, B., Shalovylo, S., Hachak, Y., Grabovska, O., Bushueva, I., Denys, G., Hudyma, V., Pakholkiv, N., Jarochovich, I., Nahirniak, T., Pavliv, O., Farionik, T., Bratyuk, V. (2020). Influence of "Thireomagnile" and "Thyrioton" preparations on the antioxidant status of pregnant cows. Ukrainian Journal of Ecology, 10(1), 122-126. doi: 10.15421/2020 19.

Kondrahin, I. P., Kurilov, N. A., \& Mlahov, A. G. (1985). Klinicheskaja laboratornaja diagnostika $\mathrm{v}$ veterinarii. M.: Agropromizdat (in Russian).

Koreiba, L. V. (2019). Hematolohichni pokaznyky u vysokoproduktyvnykh koriv v dynamitsi sukhostiinoho periodu. Naukovyi visnyk Lvivskoho natsionalnoho universytetu veterynarnoi medytsyny ta biotekhno-lohii imeni S. Z. Hzhytskoho, 21(93), 3740. doi: 10.32718/nvlvet9307 (in Ukrainian).

Koreiba, L. V., \& Duda, Yu. V. (2019). Hematolohichnyi profil u sukhostiinykh koriv za riznykh sezoniv roku. Veterynariia, tekhnolohii tvarynnytstva ta pryrodokorystuvannia: naukovo-praktychnyi zhurnal, 4, 85-90. doi: 10.31890/vttp.2019.04.17 (in Ukrainian).
Kudrjavcev, A. A., \& Kudrjavceva, L. A. (1984). Klinicheskaja gematologija zhivotnyh. M.: Kolos (in Russian).

Kulyaba, O., Stybel, V., Gutyj, B., Turko, I., Peleno, R., Turko, Ya., Golovach, P., Vishchur, V., Prijma, O., Mazur, I., Dutka, V., Todoriuk, V., Golub, O. Dmytriv, O., \& Oseredchuk, R. (2019). Effect of experimental fascioliasis on the protein synthesis function of cow liver. Ukrainian Journal of Ecology, 9(4), 612-615. https://www.ujecology.com/articles/effect-ofexperimental-fascioliasis-on-the-protein-synthesisfunction-of-cow-liver.pdf.

Levchenko, V. I., Sokoliuk, V. M., \& Bezukh, V. M. (2002). Doslidzhennia krovi tvaryn ta klinichna interpretatsiia otrymanykh rezultativ. Metodychni rekomendatsii - Bila Tserkva (in Ukrainian).

Petrovskij, G. S. (1995). Gematologicheskie pokazateli u sel'skohozjajstvennyh i domashnih zhivotnyh. Kartina krovi pri nekotoryh fiziologicheskih sostojanijah i vozdejstvijah vneshnej sredy. Veterinarnaja gematologija. M.: Kolos, 102-121 (in Russian).

Rihter, V., Verner, Je., \& Bjer, H. (1982). Osnovnye fiziologicheskie pokazateli u zhivotnyh i tehnologija soder-zhanija. M.: Kolos (in Russian).

Simonjan, G. A., \& Hisamutdinov, F. F. (1995). Veterinarnaja gematologija. M.: Kolos (in Russian).

Vlizlo, V. V., Fedoruk, R. S., \& Ratych, I. B. (2012). Laboratorni metody doslidzhen u biolohii, tvarynnytstvi ta veterynarnii medytsyni dovidnyk. Lviv: SPOLOM (in Ukrainian).

Zamazii, A. A., Kambur, M. D., \& Lisovenko, V. M. (2015). Fiziolohichni vlastyvosti krovi tilnykh koriv. Visnyk Sumskoho natsionalnoho ahrarnoho universytetu. Seriia :Veterynarna medytsyna, 1, 4245. http://nbuv.gov.ua/UJRN/Vsna_vet_2015_1_12 (in Ukrainian). 